\title{
A HELYI AKCIÓCSOPORTOK SZEREPE A VERSENYKÉPES ÉS FENNTARTHATÓ VIDÉK- FEJLESZTÉS MEGVALÓSÍTÁSÁBAN
}

\author{
(The Role of Local Action Groups in the Realization \\ of Competitive and Sustainable Rural Development) \\ KIS KRISZTIÁN - SZEKERESNÉ KÖTELES RITA
}

\begin{abstract}
Kulcsszavak:
versenyképesség fenntarthatóság LEADER-megközelités helyi vidékfejlesztési stratégia helyi akciócsoport belsö fejlesztési tényezö

A LEADER-megközelités vidékfejlesztési politika megvalósitásában játszott növekvö szerepének köszönhetöen a Helyi Akciócsoportok (HACS-ok) a vidékfejlesztés intézményrendszerének fontos szereplöivé váltak. A helyi fejlödést segitö, elömozditó tevékenységük révén térszervezö eröt jelentenek a vidéki térségekben. Müködésük hathatósan hozzájárul az európai vidékfejlesztési politika helyi szintü megvalósításához, térségük versenyképes és fenntartható fejlödéséhez. E szerepnek való megfelelés áldozatos és aktiv munkát követel az Akciócsoportoktól a programozás és a megvalósitás folyamatában egyaránt. A tanulmányban foglalkozunk az életminöség, a versenyképesség és a fenntarthatóság kérdéseivel, bemutatjuk a HACS-ok megalakulásának folyamatát, értékeljük a Helyi Vidékfejlesztési Stratégia megvalósitásának eddigi eredményeit a Hódmezövásárhelyi kistérségben, valamint vizsgáljuk a HACS-ok, mint belsö fejlesztési tényezök szerepét és feladatait a versenyképességi és fenntarthatósági célokat kitüzö vidékfejlesztési politika helyi szintü megvalósitásának folyamatában. A tanulmány elkészitése során támaszkodtunk a Magyarországon megalakult helyi akciócsoportok körében 2010 márciusában végzett, csaknem teljes körü, az akciócsoportok 94\%-ára kiterjedö kérdöives felmérésünk részeredményeire. Esettanulmányként a Hódmezöóásárhelyi kistérségben müködö LEADER HACS példáján bemutatjuk, hogy a Helyi Vidékfejlesztési Stratégiák megvalósitásában az Akciócsoportok szerepe nem szükülhet be csupán az általuk koordinált fejlesztési források elosztására. A stratégia hatékony végrehajtásához ugyanis szükség van a helyi szereplök cselekvökészségének és együttmüködésének fokozására, amely többféle feladat ellátását teszi szükségessé.
\end{abstract}

\section{Életminöség, versenyképesség, fenntarthatóság a vidékfejlesztésben}

A vidékfejlesztés általános értelemben a vidéken élő emberek életminőségének javítását jelenti (Farkas 2002). Ezzel kapcsolatban Fehér (2005) felveti azt a kérdést, hogy milyen tényezők vezetnek a jobb életminőséghez, milyen súlyuk van ezeknek az egyéni preferenciákban, s hogyan is juthatunk el annak eléréséhez. Fehér szerint az életminőség javításának gondolata jó kiindulási alapot nyújt a vidékfejlesztés meghatározásához, mert széles körü törekvéseket foglal magában. Ugyanakkor az életminőség változó értéktartalommal bíró fogalom, hiszen a különböző egyének eltérő nézetekkel rendelkeznek arról, hogy mit jelent a 'jó élet', milyen körülmények között érzi jól magát, és az adott egyénnek időben is eltérö 
nézetei lehetnek a 'jó életminőségröl' (Fehér 2005). Mindehhez fontos azonban hozzátenni, „hogy a vidékfejlesztés ugyan túlmutat a gazdasági fejlesztésen, mégis alapvető igazság, hogy az a település kínálhat életminőséget, amelyik erős gazdasági bázissal rendelkezik" (Shaffer idézi Fehér 2005, 232). Hasonlóan fogalmaz Madarász (2003) is, aki szerint a fejlődés és a fejlesztés célja az emberek jólétének fokozása, ami elképzelhetetlen gazdasági fejlődés nélkül.

Természetesen mindez nem azt jelenti, hogy a gazdasági fejlödés önmagában megoldaná a vidéki térségek valamennyi problémáját, s felszámolná valamennyi hátrányát, csupán azt, hogy a müködő és prosperáló gazdaság a területi fejlődés egyik fontos feltétele. „A gazdasági fejlődés nem jelent mást, mint az egy főre eső GDP növekedését, a gazdasági szerkezet átalakulását, s a gazdálkodás hatékonyságának emelkedését" - írja Sarudi (2003, 15). A gazdasági fejlettség és dinamikus párja, a gazdasági fejlődés általánosan alkalmazott mérőeszköze az adott térségben előállított egy főre eső GDP nagysága, illetve annak időbeli változása. Az egyes térségek fejlődését nagymértékben befolyásolja gazdaságuk versenyképessége. A versenyképesség alatt általános értelemben vállalkozások, térségek azon képessége értendő, hogy mennyire tudnak termékeikkel vagy szolgáltatásaikkal a különböző piacokon versenyben maradni, illetve helytállni. Lengyel (2000) megfogalmazását alapul véve a térségek gazdasága akkor versenyképes, ha az nyitott, az egy lakosra jutó jövedelem (GDP/fö) tartósan magas és növekvő, ezzel együtt magas szintü és nem csökkenő a foglalkoztatottsági ráta. A térségi versenyképesség tehát az adott térségben megtermelt egy lakosra jutó jövedelem nagysága és növekedési üteme, mely jövedelmet a munkatermelékenység és a foglalkoztatottság szintje határozza meg. Felmerül a kérdés, hogy a vidéki gazdaságok versenyképessége, a vidéki területek fejlődése s a vidékfejlesztés hogyan, milyen módon áll kapcsolatban - egyáltalán kapcsolatban áll-e - a fenntarthatósággal. A fenntarthatóság, illetve a fenntartható fejlődés koncepciója - mely a gazdasági, a társadalmi és a környezeti szempontok összehangolását hangsúlyozza - a 21 . században minden fejlődés, illetve fejlesztés - így a vidékfejlesztésé is - elengedhetetlen alapelve. Az előbbi kérdésre a választ Szörényiné Kukorelli $(2005,128)$ adja meg, amikor egyik cikkében arról ír, hogy „társadalmilag és gazdaságilag fenntarthatóvá egy vidéki térség csak a népességmegtartó képesség és a jövedelemtermelés fokozásával, a vidéki terek felértékelödésével és élettérként való elfogadásával válhat." Szörényiné Kukorelli szerint ,az ökológiai fenntarthatóság a társadalmi és gazdasági fenntarthatóság záloga, hiszen ahol nincs fenntartható társadalom, valamint müködő és fenntartható gazdaság, ott fenntarthatatlan folyamatok indulhatnak el a környezetet illetően is. Rövid- és középtávon csakis a versenyképes vidéki gazdaság szolgálhatja az ökológiai fenntarthatóságot... Tehát a versenyképesség és a fenntarthatóság egymást erősítő, és nem egymást kizáró fogalmak.” Ugyanakkor „,hosszú távon csakis az ökológiai fenntarthatóság tudja biztosítani a gazdasági és társadalmi fenntarthatóságot, hiszen, ha a vidék ökológiai eltartó képessége csökken, akkor a társadalmi és gazdasági fenntarthatóság zsákutcába torkoll” (Szörényiné Kukorelli 2005, 128). 
Mindezek alapján levonhatjuk azt a konklúziót, hogy a fenntartható fejlődés melynek célja az életminőség javítása a természeti környezet által megszabott lehetőségek és korlátok között - elérésének, megvalósításának szükséges eszköze a gazdasági versenyképesség. Ilyen megközelítésben, a fentiek integrálásával megfogalmazhatjuk a fenntartható vidékfejlesztés fogalmát, mely olyan beavatkozások folyamataként értelmezhető, amely a vidéki térségekben élők életminőségének jobbítására irányul oly módon, hogy a fejlesztések a fenntarthatóság szempontjainak figyelembevételével párosulnak a vidékgazdaság versenyképességére való törekvésekkel.

\section{A helyi akciócsoportok megalakulásának folyamata}

Az Európai Bizottság 2007. szeptember 19-én fogadta el az Új Magyarország Vidékfejlesztési Programot (ÚMVP), amely a 2007-2013 közötti időszakra vonatkozóan határozza meg a főbb hazai vidékfejlesztési irányvonalakat és tartalmazza ennek feltételrendszerét. Vidékfejlesztés címén az ÚMVP négy tengelye mentén az agrárgazdaság szereplői és a vidéki térségek 4956130871 euró (1300 milliárd Ft) fejlesztési forráshoz jutnak. Ezen belül a tágabb értelemben vett vidékfejlesztésre irányuló intézkedések, mint a vidéken élők életminőségének javítása és a vidékgazdaság diverzifikálása (III. tengely), valamint a LEADER (IV. tengely) támogatására 963046471 eurót (250 milliárd Ft), azaz a fejlesztési források 19,5\%-át - III. tengely: 690690802 euró (180 milliárd Ft), 14\%; IV. tengely: 272355669 euró (70 milliárd), $5,5 \%$ - fordítják. A központi intézményrendszer az ÚMVP III-as és IV-es tengely forrásainak elosztását mintegy 15\%-ban programozza (horizontális intézkedések) és dönt a felhasználásáról (pl. alapszolgáltatások fejlesztése a vidéki térségekben, diverzifikáció, képzési programok), míg a források 85\%-ára a LEADER-típusú területi szerveződések, ún. helyi vidékfejlesztési közösségek tervezhettek (nem horizontális jellegü intézkedések). A források felosztását és felhasználását megelőző intézményesülési és tervezési folyamatot az ÚMVP megvalósításáért felelős Irányító Hatóság szerepét betöltő FVM két rendeletben (93/2007. FVM rendelet, 147/2007. FVM rendelet) szabályozta. A rendeletek által meghatározottan a helyi közösségek kiválasztása és elismerése több szakaszban történt:

1) a helyi közösségek megalakulása, nyilvántartásba vételi eljárás;

2) az elözetesen elismert vidékfejlesztési akciócsoportok kiválasztása;

3) az előzetesen elismert vidékfejlesztési akciócsoportok helyi vidékfejlesztési stratégiáinak elkészítése;

4) a helyi vidékfejlesztési közösségek (HVK-k) és a LEADER helyi akciócsoportok (LEADER HACS-ok) kiválasztása.

A 93/2007. FVM rendelet szabályozta a helyi közösségek, valamint az előzetesen elismert vidékfejlesztési akciócsoportok megalakulását, nyilvántartásba vételét, valamint elismerésének rendjét. A rendelet kihirdetésével és 2007. szeptember elsejei hatályba lépésével elindult a 2007-2013-as időszakra vonatkozó új, negyedik 
generációs LEADER-program magyarországi megvalósításának folyamata. A rendelet alapján 2007. október 10-ig a helyi szereplők országszerte 105 vidékfejlesztési közösséget hoztak létre ügyelve tagságuk belső struktúrájára, melyben a vállalkozói és civil szféra együttes részarányának legalább 60\%-ot kellett kitennie. A megalakult 105 helyi közösségböl az Irányító Hatóság (IH) döntése alapján 96 kapott elözetesen elismert vidékfejlesztési akciócsoport címet.

A 147/2007. FVM rendelet szabályozta az előzetesen elismert vidékfejlesztési akciócsoportok által készítendő helyi vidékfejlesztési stratégiák elkészítésének folyamatát, valamint a Helyi Vidékfejlesztési Közösségek és a LEADER helyi akciócsoportok kiválasztását. A rendelet értelmében a vidékfejlesztési akciócsoportoknak az elismerő határozat kézhezvételétől számított 10 munkanapon belül a tervezési folyamat lebonyolításáért felelős csoportot, ún. tervezést koordináló csoportot (TKCS) kellett létrehozniuk és bejelenteniük az IH részére. Ezt követően az előzetesen elismert vidékfejlesztési akciócsoportoknak 120 nap állt a rendelkezésükre, hogy egy Internet alapú szoftver segítségével, elektronikus felületen elkészítsék az általuk lefedett területre kidolgozott stratégiát, az ún. helyi vidékfejlesztési stratégiát (HVS).

A TKCS-k által elkészített HVS két részből áll: az ÚMVP III. intézkedéscsoportjának „mikrovállalkozások létrehozásának és fejlesztésének támogatása”, ,a turisztikai tevékenység ösztönzése”, „falumegújítás és -fejlesztés”, valamint „a vidéki örökség megőrzése és fenntartható fejlesztése" intézkedéseire épülő Helyi Vidékfejlesztési Tervböl (HVT), valamint az 1698/2005/EK rendeletben foglaltaknak megfelelö támogatási konstrukciókra épülő LEADER-tervből. A HVS tervezését az előzetesen elismert vidékfejlesztési akciócsoportok annak megfelelően, hogy az előzetes elismerés feltételeit - illetve a területi átfedések (többszörös regisztráció) megszüntetését mikor teljesítették, három szakaszban kezdték meg: az első körösök (63 közösség) 2008. január 21-én, a második körösök (26 közösség) 2008. március 10-én, a harmadik körösök (7 közösség) 2008. május 13-án. Területi átfedések annak folytán jöttek létre, hogy egy település két esetben minősült egy helyi közösség által lefedettnek: az egyik (1), ha az adott település polgármestere egyszemélyben megalakította a helyi közösséget, vagy ha tagjává vált egy helyi közösségnek; a másik (2), ha az adott településen - az előírt lakosságszámnak megfelelően legalább - egy, kettő, illetve három civil szervezet, vállalkozás vagy azok valamilyen közös csoportja alakította meg a helyi közösséget, vagy ha tagjává vált egy helyi közösségnek. Amennyiben a két lehetőség egy adott településen egymással ellentétes irányban ment végbe, úgy kialakult a területi átfedés.

Az akciócsoportoknak a rendelkezésre álló négy hónapos tervezési periódus folyamán egy előre megadott struktúrában, az IH időbeli ütemezése szerint kellett elkészíteniük a Helyi Vidékfejlesztési Stratégiájukat. A tervezés végeztével az IH értékelte a stratégiákat és döntött arról, hogy az előzetesen elismert vidékfejlesztési akciócsoportok milyen formában, a III. és IV. tengely forrásaira egyaránt jogosult LEADER Helyi Akciócsoportként (LEADER HACS) vagy csak a III. tengely forrásaira jogosult Helyi Vidékfejlesztési Közösségként (HVK) müködhetnek tovább. Az intézményesülési folyamat záró momentumaként az előzetesen elismert 
vidékfejlesztési akciócsoportoknak legkésőbb 2008. október 1-jéig, tagjaik több mint felének részvételével, jogi személyiséggel rendelkező szervezeti formává (egyesület, nonprofit Kft. vagy nonprofit Zrt.) kellett alakulniuk.

Az IH döntése értelmében mind a 96 elözetesen elismert vidékfejlesztési akciócsoport megkapta a LEADER akciócsoport elismerést és ezzel a jogosultságot a III. és a IV. tengely forrásainak felhasználására, illetve a HVS mindkét tervét - HVT és LEADER-terv - tartalmazó komplex stratégia megvalósítására. Az Irányító Hatóság által LEADER helyi akciócsoporttá minősített 96 helyi közösség (1. ábra) 3019 települést - az ország településeinek $96 \%$-át, népességének pedig 44\%-át (4,5 millió fö) és mintegy 12 ezer szervezetet foglal magába (KSH 2009). A LEADER HACS címeket a helyi közösségek képviselői 2008. szeptember 26-án, az I. Magyar Vidék Napján, ünnepélyes keretek között vehették át. Ezt követően elkezdődött egy meglehetősen lassúnak bizonyuló folyamat a Helyi Vidékfejlesztési Stratégiákban foglaltak végrehajtására, melynek első lépcsőjét a 2008 októberében megnyíló pályázati rendszer jelentette. A központi rendszer nehézkes, sokszor túladminisztrált múködése következtében immáron három pályázati fordulót, támogatási kérelem benyújtási időszakot követően még csupán az első pályázati fordulóra vonatkozó támogatási határozatok születtek meg, megvalósult, befejezett fejlesztésekröl és a támogatások kifizetéseiröl - 2010 márciusáig - ugyanakkor nem beszélhetünk.

\section{1. ÁBRA}

A LEADER Helyi Akciócsoport által lefedett települések (Municipalities Covered by the LEADER Local Action Groups)

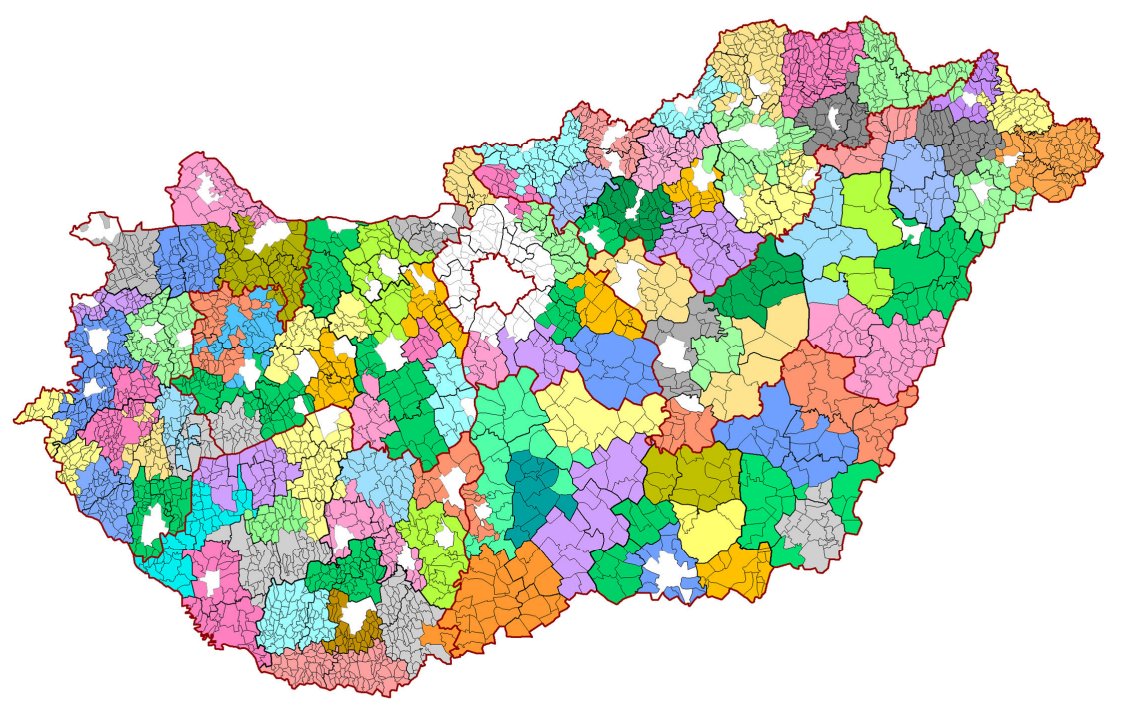

Forrás: VKSZI (2008). 


\section{A helyi vidékfejlesztési stratégia megvalósitásának folyamata és értékelése a Hódmezövásárhelyi kistérségben}

A Vásárhelyi Vidék Jövőjeért előzetesen elismert vidékfejlesztési akciócsoport stratégiáját 3828934 euró, azaz mintegy 1 milliárd Ft ÚMVP-ből finanszírozható tervezett keretösszegre dolgozta ki (1. táblázat). A stratégiában öt fejlesztési prioritás, azon belül 22 intézkedés került megfogalmazásra, melyből az öt prioritás mentén 16 intézkedésre az ÚMVP III-IV. tengelye biztosít forrásokat, a fennmaradó 6 intézkedés esetében alternatív forráscímek (DAOP, KEOP, TÁMOP) lettek megjelölve. Kalkulációnk szerint a HVS - figyelembe véve az egyes intézkedésekre allokált források összegét és a támogatási intenzitások mértékét - 5307434 euró, azaz hozzávetőleg 1,4 milliárd Ft összköltségű fejlesztést indukál majd a kistérségben.

Megjegyezzük, hogy az előzetesen elismert akciócsoportok az Irányító Hatóság erős kontrollja és az online tervezési eszköz standardizált keretei között végezték programozó, stratégiaalkotó tevékenységüket. Németh (2009) szerint azzal, hogy a hazai vidékpolitikai irányítás standardizálta a HVS tervezési folyamatát egyúttal lemondott az innovatív, esetleg „brillírozó” stratégiákról. Az előbbiek tehát nagymértékben befolyásolták az elkészült stratégiák minőségét, mivel nem tették lehetővé az akciócsoportok számára a valóban helyi igényekre, fejlesztési szükségletekre alapozott integrált, innovatív stratégiák kialakítását. Az akciócsoportok a rendelkezésükre álló III. tengelyes forrásokat például irányítottan, a már megismert négy intézkedésre jogszabályban meghatározott feltételekkel allokálhatták, ami nem kínált túl nagy szabadságot részükre. Ennél nagyobb szabadságot élvezhettek az akciócsoportok a jóval kisebb összegü LEADER kiegészítő források tervezésénél, hiszen nem volt elöírva részükre, hogy milyen intézkedésekre kell azokat fordítaniuk, így ügyelve az ÚMFT különböző operatív programjaitól való elhatárolásra - azokat szabadon tervezhették. A stratégiák LEADER-szerüségét javította, hogy az akciócsoportok törekedtek arra, hogy minél szélesebb körben felmérjék a helyi szereplök szükségleteit, fejlesztési igényeit, $\mathrm{s}$ azt a lehetőségekhez mérten beépítsék az általuk készített stratégiákba. A projektgyüjtés eredményeként a Hódmezővásárhelyi kistérségben 285 darab projektötletet, azaz a helyi szereplők által megfogalmazott fejlesztési elképzelést gyűjtött össze az akciócsoport a HVI közremüködésével. 
1. TÁBLÁZAT

A HVS forrásallokációja a prioritások és intézkedések szerint (Resource Allocation in the Local Development Plan According to the Priorities and Measures)

\begin{tabular}{|c|c|c|}
\hline Fejlesztési prioritás & Fejlesztési intézkedés & $\begin{array}{l}\text { Allokált } \\
\text { forrás } \\
\text { (euró) }\end{array}$ \\
\hline \multirow{5}{*}{$\begin{array}{l}\text { I.) A térség turisztikai vonze- } \\
\text { rejének növelése és népszerü- } \\
\text { sitése }\end{array}$} & $\begin{array}{l}\text { 1) Színvonalas szolgáltatások és } \\
\text { programok kialakítása }\end{array}$ & 658000 \\
\hline & $\begin{array}{l}\text { 2) Közösségi szálláshelyek kialakí- } \\
\text { tása, fejlesztése }\end{array}$ & 375000 \\
\hline & 3) Minőségi szálláshelyek kialakítása & 165000 \\
\hline & $\begin{array}{l}\text { 4) A települések és a térség ismert- } \\
\text { ségét, hírnevét javító rendezvények } \\
\text { szervezése }\end{array}$ & 59000 \\
\hline & I.) prioritás összesen & 1257000 \\
\hline \multirow{4}{*}{$\begin{array}{l}\text { II.) Falufejlesztés és - } \\
\text { megújitás }\end{array}$} & $\begin{array}{l}\text { 1) Településképet javító közösségi } \\
\text { terek kialakítása, meglévők fejlesztése }\end{array}$ & 570000 \\
\hline & $\begin{array}{l}\text { 2) Közösségi célokat szolgáló épüle- } \\
\text { tek felújítása, korszerüsítése }\end{array}$ & 500000 \\
\hline & $\begin{array}{l}\text { 3) Helyben termelt termékek, hely- } \\
\text { ben történő értékesítésének elősegí- } \\
\text { tése }\end{array}$ & 66494 \\
\hline & II.) prioritás összesen & 1136494 \\
\hline \multirow{5}{*}{$\begin{array}{l}\text { III.) Mikrovállalkozások fog- } \\
\text { lalkoztatás- és jövedelemter- } \\
\text { melö képességének fenntart- } \\
\text { ható fejlesztése }\end{array}$} & $\begin{array}{l}\text { 1) Feldolgozással foglalkozó } \\
\text { mikrovállalkozások létrehozása, } \\
\text { fejlesztése, korszerüsítése }\end{array}$ & 480000 \\
\hline & $\begin{array}{l}\text { 2) Szolgáltatással foglalkozó } \\
\text { mikrovállalkozások létrehozása, fej- } \\
\text { lesztése, korszerüsítése }\end{array}$ & 230000 \\
\hline & $\begin{array}{l}\text { 4) Kereskedelemmel és javítással } \\
\text { foglalkozó mikrovállalkozások létre- } \\
\text { hozása, fejlesztése, korszerüsítése } \\
\text { 5) Építőiparral foglalkozó }\end{array}$ & 125000 \\
\hline & $\begin{array}{l}\text { mikrovállalkozások létrehozása, } \\
\text { fejlesztése, korszerüsítése }\end{array}$ & 46000 \\
\hline & III.) prioritás összesen & 881000 \\
\hline \multirow{3}{*}{ IV.) Vidéki örökség megörzése } & $\begin{array}{l}\text { 1) Helyi természeti és épített örök- } \\
\text { ség megörzése, felújítása, látogatha- } \\
\text { tóvá tétele }\end{array}$ & 249520 \\
\hline & $\begin{array}{l}\text { 2) Helyi hagyományok és kultúra } \\
\text { megőrzése, fejlesztése, és bemutat- } \\
\text { hatóvá tétele }\end{array}$ & 120000 \\
\hline & $I V$.$) prioritás összesen$ & 369520 \\
\hline \multirow{3}{*}{ V.) Életminöség javitása } & $\begin{array}{l}\text { 1) Egészségmegőrző, sport és kultu- } \\
\text { rális szolgáltatások fejlesztése }\end{array}$ & 125920 \\
\hline & $\begin{array}{l}\text { 2) Civil szervezetek rendezvényeinek } \\
\text { támogatása }\end{array}$ & 59000 \\
\hline & V.) prioritás összesen & 184920 \\
\hline
\end{tabular}

Forrás: Saját szerkesztés. 
Fontosnak tartjuk kiemelni, hogy a stratégia magán viseli az allokatív tervezés jegyeit, melynek jellemzője, hogy „...a korlátozottan rendelkezésre álló forrásokat igyekszik elosztani az egymással versenyző fejlesztési szükségletek vagy felhasználók között" (Faragó 1997, 5). Az allokáció elvére épülő tervezés alapvetően visszavezethető arra, hogy a stratégia keretei jórészt rögzítettek voltak (lásd III. tengely intézkedései), ebből kifolyólag kevésbé volt lehetősége a HACS-nak, hogy valóban jövőformáló, stratégiai szemléletü tervet készítsen. Az allokatív szemlélet előtérbe kerülését erősítette, hogy a stratégiát készítők a projektgyüjtésből származó, a helyi szereplőktől beérkező, különböző fejlesztési területekre vonatkozó, eltérő számú és forrásigényü fejlesztési szükségleteket és elképzeléseket maradéktalanul be akarták építeni a HVS-be, ami a stratégia prioritásain ugyan nem - hiszen azok jórészt adva voltak -, de a források felosztásán minden bizonnyal változtatott. A stratégia évenkénti felülvizsgálata során lehetősége van ugyan a HACS-nak a forrásallokáció megváltoztatására, ez azonban csak az allokatív szemléletet, az allokáció elvére épülő tervezést erősíti, ami a stratégiai szemléletü tervezéshez képest Lengyel (2003) véleménye szerint eleve versenyhátrányt jelent.

Mivel az eddigi három pályázati forduló esetében csak az első fordulóra vonatkozóan rendelkezünk határozatokkal lezárt, azaz nyertes pályázatokkal, így a következőkben ezek vizsgálatára fókuszálunk.

2009. január 12-én zárult a 2008. október 18-án meghirdetett Új Magyarország Vidékfejlesztési Program III. tengely négy jogcímére (mikrovállalkozások létrehozása és fejlesztése, turisztikai tevékenységek ösztönzése, falumegújítás és -fejlesztés, vidéki örökség megőrzése) kiírt első támogatási kérelem (pályázat) benyújtási időszak. Ezen időszak folyamán „A Vásárhelyi Vidék Jövőjéért Egyesület” (AVVJE) munkaszervezetéhez a Hódmezővásárhelyi kistérségből összesen 25 db támogatási kérelem érkezett be.

Az akciócsoporthoz beérkezett támogatási kérelmeket az egyes jogcímrendeletek mellékletében meghatározott pontozási rendszer segítségével első körben a HACS bírálta el, $\mathrm{s}$ állította fel a támogatásra javasolt pályázatok rangsorát. Ezt követően a végső döntést a Mezőgazdasági és Vidékfejlesztési Hivatal (MVH) hozta meg. Mindez azt jelenti, hogy a HACS-oknak véleményezési szerepük volt a pályázatok támogatását illetően, de a döntés nem helyi szinten történt. Mindez egybevág a Magyar Nemzeti Vidéki Hálózat kialakításáért felelős miniszteri biztos 2008. április 14-i előadásában elmondottakkal, miszerint ,a helyi közösségek végrehajtó szerepet kapnak" (Pásztohy 2008, 12). Ez ellentmondásban van a szubszidiaritás elvével, azaz a döntéshozatal és a felelősség helyi szintre történő decentralizációjának érvényesítésével. Az előbbiekkel kapcsolatosan kérdőíves felmérésünkben arra kértük a magyarországi HACS-okat, hogy 1-től 5-ig terjedő skálán értékeljék a következőket: 1.) Milyen mértékben érvényesül a szubszidiaritás elve (helyi szintü döntéshozatal és irányítás) munkájukban?; 2.) Mennyire jellemző az Irányító Hatóság és a Közremüködő szervezet esetében a szubszidiaritás elvének megfelelő magatartás, 
azaz mennyire segítik elő (szubszidiálják) a döntéshozatal decentralizációját, a helyi szintü irányítás és menedzsment tényleges megvalósulását?; 3.) Milyen mértékben tudja érdekeit érvényesíteni a HACS a vidékfejlesztés intézményrendszerének felsőbb szintjein, azaz egy vagy kétirányú a kapcsolat, illetve a kommunikáció a központ és a lokalitás között? Az első kérdésre 3,5-ös átlagértéket számoltunk, ami azt jelenti, hogy a döntések egy része helyi szinten születik, a HACS-ok korlátozott önállósággal vesznek részt a döntéshozatalban, érvényesül a központi irányítás kontrollja. A második kérdésre adott pontértékek átlaga 3,1 volt, amely szerint a vidékfejlesztés intézményrendszerének magasabb szintű szerveződései korántsem tesznek eleget annak érdekében, hogy elömozdítsák a döntéshozatal decentralizációját. Az előbbieket erősíti meg a harmadik kérdésre adott 2,9-es átlagpontérték, ami szerint a HACS-ok úgy vélik, hogy a szintek közötti kommunikációban nagyobbrészt a központi akarat érvényesül, rájuk jobbára végrehajtó szerep hárul.

Az első támogatási kérelem benyújtási időszakban a HACS munkaszervezetéhez beadott pályázatok épület-beruházásokra, müszaki-technológiai és ügyviteltechnikai fejlesztésekre, minőségbiztosítási, -irányítási rendszerek kiépítésére, szálláshelyek kialakítására, bővítésére, turisztikai szolgáltatások színvonalának javítására, valamint falufejlesztésre irányultak, illetve irányulnak.

A támogatási kérelmek benyújtását követően, 2009. január végére a HACS döntött az egyes jogcímekhez tartozó elözetes támogatási rangsorokról, s megküldte a pontozási jegyzőkönyveket az MVH-nak, az előzetes támogatási rangsort pedig az Irányító Hatóságnak. Ezt követően történtek meg a támogatási kérelmet benyújtók helyszíni ellenőrzései az MVH és a HACS közremüködésével. A támogatási rangsor jóváhagyására, illetve a támogatási határozatok meghozatalára azonban sokáig kellett várniuk a pályázóknak. Valamennyi kedvezményezett 2009. szeptember 30-ig kapta kézhez a támogatási határozatot, s csak ezt követően indulhattak meg a várva várt fejlesztések.

A benyújtott 25 pályázat közül az AVVJE javaslata alapján s az MVH végső döntése értelmében 16 részesült kedvező elbírálásban. Falufejlesztésre Mártély és Székkutas, a kistérség két községének önkormányzata nyújtott be sikeres pályázatot. A turisztikai tevékenységek ösztönzésére benyújtott nyolc pályázatból négy részesült kedvező elbírálásban. A mikrovállalkozások létrehozása és fejlesztése intézkedés keretében tizenötből tíz pályázat nyert el támogatást, a vidéki örökség megőrzése intézkedésre pedig nem érkezett pályázat a HACS-hoz. A nyertes pályázatok pénzügyi adatait mutatja be jogcímek szerint a 2. táblázat.

Az adatok összesítése után kiderül, hogy az első pályázati fordulóban nyertes pályázók összesen mintegy 290 millió forint vissza nem térítendő támogatáshoz juthatnak, melynek segítségével csaknem 450 millió forint értékü fejlesztést valósíthatnak meg a kistérségben.

A következőkben a fenntarthatósági és versenyképességi követelményeknek megfelelöen öt szempont szerint vizsgáljuk a nyertes első fordulós pályázatokat. 
2. TÁBLÁZAT

Az elsö pályázati forduló nyertes pályázatainak összesitett pénzügyi adatai (The Comprehensive Financial Data of the Winning Proposals in the First Submission Period)

\begin{tabular}{|c|c|c|c|c|}
\hline Támogatási jogcím & $\begin{array}{l}\text { Igényelt } \\
\text { támogatás } \\
(F t)\end{array}$ & $\begin{array}{c}\text { Teljes } \\
\text { projektméret } \\
\text { (Ft) }\end{array}$ & $\begin{array}{l}\text { Támoga- } \\
\text { tási in- } \\
\text { tenzitás } \\
(\%)\end{array}$ & $\begin{array}{c}\text { Átlagos } \\
\text { projektméret } \\
(\text { Ft })\end{array}$ \\
\hline $\begin{array}{l}\text { Mikrovállalkozások } \\
\text { létrehozása és } \\
\text { fejlesztése }\end{array}$ & 126899079 & 212875088 & 60 & 21287509 \\
\hline $\begin{array}{l}\text { Turisztikai tevé- } \\
\text { kenységek ösztön- } \\
\text { zése }\end{array}$ & 90209472 & 147721643 & 61 & 36930411 \\
\hline $\begin{array}{l}\text { Falumegújitás és } \\
\text {-fejlesztés }\end{array}$ & 72487375 & 85528218 & 85 & 42764109 \\
\hline $\begin{array}{l}\text { Vidéki örökség } \\
\text { megörzése }\end{array}$ & - & - & - & - \\
\hline
\end{tabular}

Forrás: Saját szerkesztés.

Mindenekelőtt szükséges leszögezni, hogy a stratégiában foglalt célok és prioritások a helyi szereplők által végrehajtott konkrét projektek formájában valósulnak meg. Ebből következően mindenképpen szükség van a projektgazdák által kimunkált és a HACS-okhoz beadott pályázatokra. A hatékony forrásfelhasználás ugyanakkor megköveteli, hogy olyan magas színvonalú, releváns, elöremutató, innovatív projektek, illetve pályázatok versenyezzenek a HACS-ok által koordinált fejlesztési forrásokért, amelyek összhangban állnak a fejlesztési stratégiáikkal és megfelelnek a LEADERprogram filozófiájának. Fontos tehát a pályázatok minősége, amelyről a pályázatok értékelése során kialakított pontszámok nyújthatnak némi információt. Megjegyezzük, hogy a pályázatok értékelés során „nyújtott” teljesítménye alapvetően függ az értékelési szempontoktól, azok relevanciájától, teljesíthetőségétől, illetve azok súlyozásától, azaz az egyes szempontokhoz rendelt pontértékektől. A 16 nyertes pályázat pontszámait vizsgálva megállapítható, hogy azok átlagosan a maximális pontszám 66\%-át érték el. 11 olyan pályázat van, ami nem éri el a maximális pontszám 70\%-át, s csak 5 olyan akad, amelyik meghaladja azt. Mindez nem fest túl biztató képet, hiszen ahogy a stratégia, úgy a pályázatok minősége is implicit módon, de mindenképpen befolyásolja a térség gazdasági fejlődését, illetve a térségi versenyképességet.

A területpolitikai döntésekkel szemben támasztott általános elvárás, hogy társadalmilag igazságosak, ugyanakkor gazdaságilag hatékonyak legyenek. Főként a Lisszaboni Stratégia hatására a területpolitikai gyakorlatban is meghatározóvá vált a versenyképesség javítására való törekvés, amelynek fő meghatározója a gazdasági racionalitás (Faragó 2006). A fejlesztési források hatékony felhasználása tekintetében - összefüggésben a térségi versenyképességgel - megvizsgáltuk a „mikrovállalkozások létrehozása és fejlesztése" intézkedésen belül tervezett fejlesztések 
eredményeként létrejövő új munkahelyek számát, azok fajlagos költségét, valamint a beruházások hatékonyságát kifejező megtérülési időt.

Az intézkedés keretében a 10 nyertes vállalkozás 16 új munkahely létrehozását vállalta. Ez a szám csak kettővel több, ha valamennyi nyertes pályázatot figyelembe vesszük. Átlagosan tehát egy vállalkozás 1,6 új munkahelyet hoz létre. Hét vállalkozás 1 , egy vállalkozás 2 , míg két vállalkozás 3 új munkahelyet szándékozik létrehozni. Nehéz ezeket a számokat önmagukban értékelni, hiszen minden új munkahely létrehozása növeli a foglalkoztatást, de felmerül a kérdés, hogy milyen áron.

A vizsgált 10 mikrovállalkozás által létrehozandó 16 új munkahely 127 millió $\mathrm{Ft}$ támogatási összeg, illetve 213 millió Ft összértékủ beruházással jöhet majd létre a kistérségben. Ennek megfelelően egy új munkahely létrehozásához átlagosan 7,9 millió Ft támogatást, illetve 5,4 millió Ft egyéb forrást, összesen 13,3 millió Ft-ot használnak majd fel a vállalkozások. Egységnyi új munkahely létrehozásának támogatásigénye 2,2 és 18,2 millió $\mathrm{Ft}$, míg az összes bekerülési költség 3,5 és 30,7 millió $\mathrm{Ft}$ között változik. Az iparági átlagos értékek ismerete nélkül nehéz helytálló véleményt mondanunk az előbbiekről, de az biztos, hogy a fenti fajlagos támogatási összegek mellett a kistérség nyertes vállalkozói ezen értékelési szempont legmagasabb pontértékeit érték el (0-10 MFt/új munkahely 18 pont, 10-20 MFt/új munkahely 14 pont) pályázatuk bírálata során.

A beruházás-gazdaságossági vizsgálatok egyik fontos mutatószáma a megtérülési idő, amely megmutatja, hogy a befektetett tőke a vállalkozás hányadik évében fizetődik vissza, illetve térül meg. Ebből adódóan a megtérülési idő a gazdasági racionalitás, a fejlesztések életképességének egyik igen fontos mérőszáma. A vállalkozások által tervezett beruházások átlagos megtérülési ideje 19,4 év, ami soknak mondható. Viszont, ha eltekintünk a két extrém magas megtérülési időt (67 és 51 év) produkáló vállalkozás adatainak számbavételétől, a fennmaradó kilenc vállalkozás esetében 10,6 évre csökken az átlagos megtérülési idő hossza, ami piacgazdasági körülmények között jónak nevezhető. Természetesen nagyon nagy különbségek lehetnek az egyes tevékenységek jövedelmezőségei között, amit az is alátámaszt, hogy a négy legkedvezőbb megtérülési időt (4, 5, 6 és 7 év) mutató vállalkozás nyerte el a legnagyobb támogatást és valósítja majd meg a legnagyobb összegü beruházást. Egyetértünk Рорр (2009) azon véleményével, miszerint ,a projektek induló támogatása csak életképes üzleti elképzelések esetében hasznos, egyébként a támogatás pazarlásáról van szó". Ezért véljük úgy, hogy a megtérülési időnek mindenképpen helye van, illetve helye lenne - mivel jelenleg nem szerepel - az értékelési szempontok között.

Az értékelési szempontok kapcsán fontosnak tartjuk megjegyezni, hogy a pályázatok bírálatánál a stratégiához való illeszkedés csak egy szempontként jelent meg, nem pedig eleve szükséges feltételként. Ilyen feltételek között a HVS fejlesztés-koordináló szerepe mindenképpen háttérbe szorul. A HVS lényege pedig az, hogy koordinálja a helyi szintü fejlesztéseket, amelynek révén realizálhatók a benne megfogalmazott célok.

Ma már nem kérdés, hogy a különbözö típusú fejlesztések megvalósításánál tekintettel kell lenni az ökológiai fenntarthatóságra. Mindezt a Göteborgi Stratégia, az 
Unió fenntartható fejlődési stratégiája is megerősíti, hiszen a stratégia a gazdasági növekedés és a társadalmi kohézió megteremtésén túl, a természeti és környezeti vonatkozásokat is beépíti az uniós politikák fenntarthatósággal kapcsolatos szempontrendszerébe.

A pályázatok értékelésénél minden jogcímnél megjelentek bizonyos környezetvédelmi szempontok is. A 16 nyertes pályázatból azonban mindössze 4 olyan akadt, amelyben a pályázó vállalta az ökológiai fenntarthatósággal összegfüggő szempontok teljesítését. A mikrovállalkozások esetében 10 nyertes pályázatból csupán 1 vette figyelembe, illetve vállalta a szempontként értékelt környezeti minőségirányítási rendszer bevezetését. A turisztikai pályázatok körében 2 nyertes tervezi a megújuló erőforrások használatát, vagy az energiahatékonyság követelményeinek megfelelö, környezetbarát technológiák alkalmazásának bevezetését. A falufejlesztési pályázatoknál az értékelési szempontként megjelenő zöldterület növelést a 2 nyertesből 1 tervezi megvalósítani. Ez az arány a fenntarthatóság tényleges érvényre jutása szempontjából csekélynek mondható. Ennek hátterében több dolog is állhat, például az, hogy az ökológiai szempontok érvényesítése bizonyos esetekben ütközhet a versenyképességi kritériumokkal, azonban úgy gondoljuk, hogy a legtöbb esetben nem erről, hanem sokkal inkább szemléletbeli hiányosságokról beszélhetünk, ami alapvetően meghatározná a fenntarthatóságot, hiszen az nem más, mint „... szemlélet-, gondolkodás-, élet-, termelési, valamint fogyasztási mód..." (Csete 2005, 5).

\section{A Helyi Akciócsoportok, mint belsö fejlesztési tényezök szerepe a versenyképes és fenntartható vidékfejlesztés megvalósitásában}

E fejezetben esettanulmányként - „A Vásárhelyi Vidék Jövőjéért Egyesület” (AVVJE) munkatársaival készített interjúinkra és a velük folytatott konzultációk során nyert információkra alapozva - mutatjuk be a HACS-ok szerepét és fontosabb feladatait. A fejezet tárgyalásánál támaszkodunk az országos felmérésünk eredményeire is.

A vidékfejlesztési politikát érvényre juttató intézményrendszer fontos elemei a LEADER-program keretében - a vidéki térségekben Európa-szerte megalakult fejlesztő szervezetek, a HACS-ok, melyek feladata a fenntartható fejlődésre irányuló helyi stratégiák kialakítása és végrehajtása. Az előbbiekből adódóan müködésükkel a HACS-ok fontos szerepet játszanak a vidékpolitikai célok helyi szintű megvalósításában. A HACS-ok szerepe a források hatékony felhasználásában - összhangban a stratégia megvalósításával - azonban nem ér véget a tervezéssel, a (kis)térségi fejlesztési stratégiák kialakításával. Mivel a források felhasználása, a konkrét tevékenységek, fejlesztések megvalósulása projektszinten történik, a fejlesztési források sikeres és hatékony felhasználásának megalapozásához szükség van a helyi szereplők kapacitásépítésére, cselekvőkészségének fokozására. A stratégia hatékony végrehajtása, az adott vidéki térség fejlődésének előmozdítása tehát folyamatos, aktív munkát igényel, melynek során a HACS-oknak térségük fejlődésének valós szervező erőivé kell válniuk. 
3. TÁBLÁZAT

A HACS-ok feladatai az általuk meghatározott fontossági sorrendben (The Importance of the LAGs' Tasks in Accordance with their Assesment)

\begin{tabular}{lc}
\hline \multicolumn{1}{c}{ Feladat megnevezése } & $\begin{array}{c}\text { Átlagos } \\
\text { pontérték }\end{array}$ \\
\hline 1) Hálózatépítés más térségekben müködő akciócsoportokkal & 6,9 \\
2) A jó gyakorlatok megosztása és elterjesztése & 5,6 \\
3) Fenntartható fejlödés koncepciójának elterjesztése és & 5,4 \\
gyakorlatba való átültetésének előmozdítása & 5,3 \\
4) Konzultáció, véleménycsere biztosítása & 5,1 \\
5) A helyi szereplők kapacitás építése (oktatás, képzés & \\
útján) & \\
6) A helyi szereplők ösztönzése közös projektek, multi- & \\
szektorális tevékenységek létrehozására, szinergia, közös & 3,9 \\
vállalkozás érdekében, mely a térség gazdasági versenyké- & \\
pességét erősítheti & \\
7) Térségi kapcsolatok erősítése, partnerségépítés a térségi & 3,3 \\
szereplők körében (a helyi szereplők összehozása) & \\
8) A helyi gazdaság élénkítése információk áramoltatásán & 2,9 \\
keresztül & 2,2 \\
9) Támogatási források nyújtása/odátélése &
\end{tabular}

Forrás: Saját szerkesztés.

Az országos felmérésben csokorba szedtük azokat a feladatokat, teendőket, amelyeket véleményünk szerint fel kell vállalniuk a HACS-oknak annak érdekében, hogy az előbbi kihívásnak megfeleljenek. A téma kapcsán arra kértük az akciócsoportokat, hogy fontosságuk szerint, 1-től 9-ig terjedő skálán priorizálják azokat. A felmérés eredményei alapján a HACS-ok a 3. táblázatban foglaltaknak megfelelően határozták meg az általuk ellátandó feladatok fontossági sorrendjét. A fentiekből világosan kiderül, hogy a HACS-ok feladata nem korlátozódhat le csupán a források allokálására és azok odaítélésére, a pályázatok értékelésére, müködésük jóval szélesebb tevékenységi kört fog át, melyben a partnerségépítés, az együttmüködések generálása, a képességek fejlesztése, a fenntartható fejlődés előmozdítása, a fejlesztések összekapcsolására, komplexitására való törekvés fontos szempontként jelennek meg.

Korábban már utaltunk rá, hogy a stratégiában foglalt célok és prioritások a helyi szereplők által végrehajtott konkrét projektek formájában valósulnak meg. Ebből adódóan egyaránt fontos tehát a pályázatok mennyisége és minősége. A megfelelő számú és minőségủ pályázat szempontjából alapvető fontosságú a HVS-ben foglalt célok, prioritások és intézkedések megismertetése a helyi szereplőkkel. A tájékoztatás, a program publicitása biztosítja, hogy a projektgazdák megismerhessék a stratégia által nyújtott lehetöségeket, és felkeltse a stratégiához kapcsolódó projektekben 
érintett helyi szereplők érdekeltségét, ami közvetve vagy közvetlenül, de befolyásolja a helyi szereplök döntéseit és azokon keresztül a területi folyamatok alakulását.

Az elöbbiekkel összhangban az AVVJE tevékenységei között fontos szerepet kap az összefogás és az együttmüködés hangsúlyozása, a program által kínált lehetőségek bemutatása és az Akciócsoport tevékenységeivel összefüggő tájékoztatás nyújtása különbözö rendezvényeken (tájékoztató fórumok, népszerüsítő rendezvények), illetve a helyi és térségi médiákban. Emellett az Egyesület saját kiadványt jelentet meg és honlapot üzemeltet. Az Egyesület munkatársainak véleménye szerint a kommunikációs tevékenység eredménye tetten érhető a hozzájuk benyújtott pályázatok számának növekedésében is. Ezt bizonyítja, hogy a III. tengelyes intézkedésekre kiírt 2009. november 16-tól 2009. december 20-ig tartó, második pályázati ciklusban már $42 \mathrm{db}$, az első ciklushoz képest 40\%-kal több beérkezett pályázatot regisztráltak. Ezt megelőzően pedig a 2009. október 1-je és 2009. november 16-a között, az első IV. (LEADER) tengelyre kiírt pályázati szakaszban 22 pályázat került benyújtásra.

Felmérésünkben arról is megkérdeztük a HACS-okat, hogy részt vesznek-e a helyi szereplők, a majdani pályázók projektjeinek kidolgozásában, a projekttervezés folyamatában. Véleményünk szerint ez azért fontos, mert a magas színvonalú projektek kidolgozása nemcsak a pályázati források elnyerésének esélyeit növeli, hanem a fejlesztések versenyképességének és hosszú távú fenntarthatóságának is záloga. Az eredmények alapján a HACS-ok is hasonlóan vélekednek, ugyanis $90 \%$-uk részt vesz a projekttervezés folyamatában, ily módon is elősegítve térségük fejlödését. A projektek kidolgozásában a HACS-ok többféle formában vesznek részt, leggyakrabban ügyfélfogadás keretében (HACS-ok 90\%-a) és/vagy konzultációs napokat és fórumokat szerveznek a témában. Az AVVJE is elsősorban ügyfélfogadás és konzultációs napok szervezésével vesz részt a projekttervezésben. A heti rendszerességgel megtartott fogadóórákon a szakemberek személyre szabott tanácsadással segítik a konkrét projektek előkészítését és kidolgozását, a feltételek, igények és lehetőségek figyelembevételével. Emellett az Akciócsoport a HVS végrehajtásában közremüködők felkészítésére, projektjeik, pályázataik színvonalas kidolgozását és végrehajtását segitő képzéseket szervez és tart pályázatírás és projektmenedzsment témakörökben. A 2009 folyamán nagy sikerrel zajlott alap- és mesterszintủ tréningeken 100 fö vett részt a kistérségből.

Bár a HACS-ok által koordinált fejlesztési források egyedi projekteket támogatnak, mégis úgy gondoljuk, hogy - összhangban a LEADER lényegével - szükség van a helyi szereplők együttműködésére, nemcsak a helyi akciócsoportok létrehozásában, a helyi közösségi kezdeményezések megfogalmazásában, a stratégia kialakításában, hanem annak megvalósításában is. A fejlesztések komplexitása úgy érhető el, ha az egyedi projektötletek találkoznak, majd összekapcsolódva, egymásra épülve egy müködő rendszert hoznak létre. A helyi szereplök együttmüködése ugyanis lehetővé teszi fejlesztéseik, illetve tevékenységeik összehangolását, összekapcsolását. Ily módon elérhetö, hogy ne különálló, egymástól elszigetelt projektek valósuljanak meg, hanem egy összefüggő rendszer, struktúra jöjjön létre. Ezzel kapcsolatban arra kértük a HACS-okat, hogy 1-től 5-ig terjedő skálán véleményezzék azt, hogy a hozzájuk 
benyújtott pályázatok milyen mértékben épülnek egymásra, milyen szintü a szinergia azok között. A kérdésre adott válaszok összesített eredménye alapján - 2,5-ös átlag (AVVJE: 2) - elmondható, hogy a projektek csak kis mértékben kapcsolódnak össze. Ennek indokaként több tényezőt említhetnénk (dezintegrált közösségek, ismeretek és információk hiánya stb.), ugyanakkor meg kell említenünk - a LEADER-típusú kísérleti program és az AVOP LEADER+ intézkedése ellenére az endogén fejlesztés elveire épülő LEADER-programmal kapcsolatos általános tapasztalatlanságot. Sokak számára a LEADER ugyanis egy újabb pályázati lehetőséget jelent, mintsem egy alulról szerveződő, helyi részvételen és együttmüködésen alapuló társadalmi tőkét erősítő programot.

A HACS-ok, amelyek maguk is együttmüködés révén jöttek létre fontos szerepet töltenek be a térségi szereplők - további - együttmüködéseinek kialakításában. Ezt bizonyítja, hogy a felmérésben megkérdezett akciócsoportok fele vélte úgy, hogy tevékenysége hathatósan hozzájárul a területi aktorok együttmüködésének kialakulásához. A HACS-ok másik felének - köztük az AVVJE - véleménye szerint az együttmüködésekhez csak részben, bizonyos mértékben tudnak hozzájárulni. Mindez biztató, hiszen az együttmüködések terjedése nagymértékben előmozdíthatja a helyi közösségek cselekvőképességének fejlődését és a közösségi kezdeményezéseik eredményes megvalósulását. Ehhez azonban mindenképpen szükség van együttmüködési készségre és bizalomra.

Tapasztalataink szerint a partneri kapcsolatok a kistérségben szükösnek mondhatók, így az együttgondolkodás és a tevékenységek összehangolásának feltételei korlátozottak. Sajnos a településeken és a kistérségben létező széthúzó erők erősebbek, mint az összekötő kapocs, hiányzik egy olyan vezető, összetartó, közösségszervező erő, amely meghatározó szerepet játszik a térségi szereplők összekovácsolásában, és képes a kölcsönös előnyök mentén létrejövő és müködő társadalmi kooperáció kialakítására. Ebben főként a települési önkormányzatok - akik nélkül egyébként sem beszélhetünk sikeres vidékfejlesztésről - és a többcélú kistérségi társulás játszhatnának jelentős szerepet, de mellettük mindenképpen megemlítendök a közösségszervező erővel bíró civil szervezetek és vállalkozások, illetve a mögöttük álló személyek (Kis-Szekeresné Köteles 2008). Az akciócsoport már a tervezés során szembesült azzal a ténnyel, hogy milyen nehéz is mozgósítani, aktivitásra ösztönözni a fejlesztésben érdekelt szereplőket.

A közösség aktivizálását, a helyi cselekvők együttgondolkodásra, együttmüködésre sarkallását szolgálják a HACS által több-kevesebb sikerrel megszervezett tematikus fórumok, workshop-ok. Példaként említjük a „Fogjunk Össze!” konferencia- és fórumsorozat első, „A Vidék Turizmusáért” elnevezésű rendezvényét, melynek sikerességét bizonyítja a nagyszámú érdeklődő mellett, hogy a megjelentek egy közös turisztikai adatbázis létrehozásában egyeztek meg, mely minden, a megyében működő HACS honlapján elérhető lesz. A rendezvény résztvevői kezdeményezték, hogy közös turisztikai programcsomag kidolgozását vállalja fel az AVVJE, illetve keressen lehetőséget az ágazat szereplőinek további tájékoztatására, tapasztalat cseréjére. 
A HACS-ok többféle feladatának ellátásához kapcsolódik a fejlesztésben érintett, illetve érdekelt helyi és térségen kívüli szereplőkkel folytatott kapcsolattartás, hálózatépítés és együttmüködés. Ezek a tevékenységek hozzájárulnak az információk hatékonyabb elterjesztéséhez, a jó gyakorlatok és tapasztalatok átadásához, az innovációk terjedéséhez, az együttmüködések ösztönzéséhez. Felmérésünkben a HACS-ok 80\%-a - köztük az AVVJE - mondta, hogy más akciócsoporttal is együttmüködik az országban és $40 \%$-a, hogy transznacionális együttmüködésben vesz részt. A HACS-ok 44 olyan területet jelöltek meg, amelyben hazai akciócsoportokkal müködnek együtt, és 30 olyat, amelyben a partner külföldi.

A fentiekben bemutatott feladatok ellátása jelentősen hozzájárul a stratégiák, illetve a vidékpolitikai célok helyi szintű megvalósulásához, mely a helyi közösségek hosszú távú életképességét és jólétét szolgálja. Fontosnak tartjuk azonban megjegyezni, hogy a HACS-ok müködése és a LEADER-módszer alkalmazásának sikere nagymértékben múlik a vidékfejlesztési program megvalósítását irányító minisztérium (IH) és az abban közremüködő szervezet, a Mezőgazdasági és Vidékfejlesztési Hivatal (MVH) jogszabályalkotó- és alkalmazó, valamint együttmüködő és koordináló szerepétől. A LEADER pályázati rendszer központi működését érő kritikák, mint a pályázatok kiírása, benyújtása és értékelése körüli anomáliák, a pályázati adminisztráció nehézségei, a müködésfinanszírozási problémák stb. rámutatnak a rendszer azon hibáira, amelyek nehezítik a HACS-ok müködését és rontják a helyi fejlesztőmunka hatékonyságát. A problémák és ellentmondások szükséges kiküszöbölésével a jövőben remélhetőleg javulni fog a rendszer müködésének hatékonysága, s eloszlanak a LEADER-megközelítés hazai alkalmazása fölött felgyülekezett viharfelhők.

Konklúzióként megfogalmazhatjuk, hogy a LEADER-típusú fejlesztések sikerét alapvetően a helyi társadalmak cselekvőképességének szintje határozza meg. A HACS-ok proaktív müködése, helyi társadalomszervező tevékenysége nagymértékben hozzájárulhat az ott élők önszerveződő és érdekérvényesítő képességének javításához. Ehhez azonban időre van szükség, ami években mérhető(!). Ebből adódóan a magunk részéröl a LEADER-program 2007-2013 közötti magyarországi megvalósításának legfőbb eredményeként azt várjuk, hogy a helyi közösségekben vagy legalábbis azok nagy részében - kiépülnek és megerősödnek azok a képességek, amelyek révén a közösségek alkalmassá válnak a helyi fejlődés irányítására, közös céljaik eredményes és fenntartható megvalósítására.

\section{Irodalom}

Csete L. (2005) Az agrár- és vidékfejlesztés fenntartható rendszere. - Gazdálkodás. 2. 3-15. o.

Faragó L. (1997) Tervezéselméleti alapvetések. - Tér és Társadalom. 1. 1-15. o.

Faragó L. (2006) A területfejlesztés tabui és téveszméi. - Élet és Irodalom. 32.

Farkas T. (2002) Vidékfejlesztés a fejlődéselméletek és a fejlesztési koncepciók tükrében. - Tér és Társadalom. 1. 41-57. o.

Fehér A. (2005) A vidékgazdaság és a mezögazdaság. Agroinform Kiadó, Budapest.

Kis K.-Szekeresné Köteles R. (2008) A negyedik generációs Leader-tervezés tapasztalatai a Hódmezővásárhelyi kistérségben. - A Falu. 3. 17-29. o. 
KSH (2009) A vidékfejlesztés helyi térségei (LEADER térségek). - Statisztikai tükör. 103. 1-9. o. http://portal.ksh.hu/pls/ksh/docs/hun/xftp/stattukor/regiok/debrecenvidekfejl.pdf

Lengyel I. (2000) A regionális versenyképességröl. - Közgazdasági Szemle. 12. 962-987. o.

Lengyel I. (2003) Verseny és területi fejlödés: térségek versenyképessége Magyarországon. JATEPress, Szeged.

Madarász I. (2003) Mezőgazdaság és vidékfejlesztés. TSF MFK, Mezőtúr.

Németh S. (2009) Az integrált és komplex vidékfejlesztés 2007-2013. - A Falu. 4. 77-90. o.

Pásztohy A. (2008) A vidékfejlesztés esélyei az Új Magyarország Vidékfejlesztési Program tükrében. http://www.mnvh.eu/sites/default/files/Esely.pdf

Popp J. (2009) Milyen lesz a Közös Agrárpolitika 2013 után? - A Falu. 4. 23-41. o.

Sarudi Cs. (2003) Térség- és vidékfejlesztés. A magyar térgazdaság és az európai integráció. Agroinform Kiadó, Kaposvár.

Szörényiné Kukorelli I. (2005) A fenntartható fejlödés stratégiai elemei a rurális térségekben. - Tér és Társadalom. 3-4. 111-137. o. 


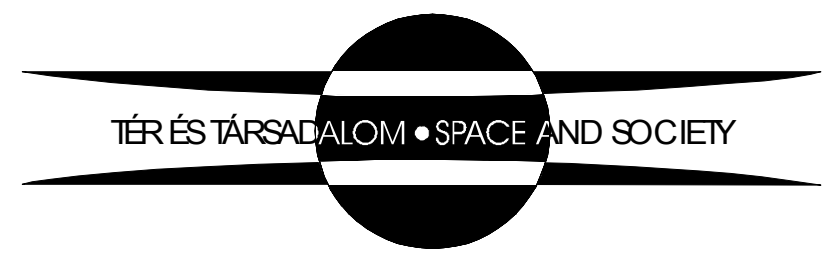

